\title{
DEGRADATION OF 4-METHYLPYRIDINE BY ARTHROBACTER SP.
}

\section{F.M. KHASAEVA ${ }^{1}$, I.A. PARSHIKOV² AND E.I. ZARAISKY ${ }^{2}$}

\author{
${ }^{1}$ Department of Microbiology of Kabardino-Balkarian State Agrarian University of V.M. Kokov, \\ Nalchik, Russia \\ ${ }^{2}$ Institute of Applied Mechanics, Russian Academy of Sciences, Moscow, Russia
}

(Received 23 September, 2015; accepted 25 Novemebr, 2015)

Key words : Biodegradation, 2,4-dimethylpyridine, Àrthrobacter sp., Bacteria

\begin{abstract}
Absrtact - In the process of degradation of 4-methylpyridine by bacterium Àrthrobacter sp. KM-4MP were isolated two metabolites and identified as 4-methylpyridin-2-ol and 8-hydroxy-4-methylidene- $1 \mathrm{H}$ cyclopenta[1,2-b:3,4-c']dipyridine-2,3,5,7(4H,6H)-tetrone.
\end{abstract}

\section{INTRODUCTION}

Development of the chemical industry led to the contamination of the biosphere by the hazardous substances. Very harmful pollutants are heterocyclic organic compounds. Derivatives of pyridine are an important class of heterocyclic compounds. They contained in wastewater of chemical plants, plants of the production of synthetic rubber, plastics, dyes (Dobson et al., 1985; Pereira et al., 1988; Rogers et al., 1985). Pure pyridines are widely used as reactants in the production of agricultural chemicals, such as herbicides and also pharmaceuticals (Kaiser et al., 1996; Khasaeva and Parshikov. 2015; Parshikov and Khasaeva, 2015; Parshikov, 2015a,b).

\section{MATERIALS AND METHODS}

The object of the researches served the strain of the bacterium Àrthrobacter sp. KM-4MP obtained from the collection of microorganisms of the Department of Microbiology, Moscow State University.

To study of the degradation of 4-methylpyridine (I) was used the synthetic medium having the following composition $(\mathrm{g} / \mathrm{L}): \mathrm{Na}_{2} \mathrm{HPO}_{4}-4.26$; $\mathrm{KH}_{2} \mathrm{PO}_{4}-2.65 ; \mathrm{MgSO}_{4} \cdot 7 \mathrm{H}_{2} \mathrm{O}-0.2 ; \mathrm{FeSO}_{4} \cdot 7 \mathrm{H}_{2} \mathrm{O}-$ $0.01 ; \mathrm{CaCl}_{2} \cdot 2 \mathrm{H}_{2} \mathrm{O}-0.02 ; \mathrm{MnSO}_{4} \cdot \mathrm{H}_{2} \mathrm{O}-0.002$; $\mathrm{Na}_{2} \mathrm{MoO}_{4}-0.001$; deionised water $-1 \mathrm{~L}$; $\mathrm{pH} 7.0-$ 7.2. Cultivation was carried out in flasks $(750 \mathrm{ml})$ with $200 \mathrm{ml}$ of a medium on a shaker $(200 \mathrm{rpm} / \mathrm{min})$ at $28-30^{\circ} \mathrm{C}$.

As the source of carbon and nitrogen in the liquid medium was added $1.5 \mathrm{~g} / \mathrm{L} 4$-methylpyridine. The degradation process was performed for 36 hours.

Degradation products were extracted with chloroform and after evaporation were dissolved in 0.5-1.0 $\mathrm{ml}$ of ethanol and had been conducting separating on chromatographic plates of "Silufol UV-254" (DC-Alufolies Kieselgel 60 F254, Merck, Germany). For chromatography were used the following solvent systems:

1. Chloroform - methanol (20:3);

2. Chloroform - acetone - ethanol (7:2:2);

3. Ethanol - ammonia - water (20:1:4);

4. Ethyl acetate - petroleum ether (5:1).

Chromatograms were visualized in UV light or iodine vapors. For the preparative isolation of individual products was used column chromatography (Silicagel L 40/100, Chemapol, Czech Republic) in a solvent system 3, and preparative thin layer chromatography in solvent systems 2, 3 and 4. Electron ionization (EI) mass spectrometry was performed at an electron energy of $70 \mathrm{eV}$ on the instrument Finigan MAT-4615. ${ }^{1} \mathrm{H}$ nuclear magnetic resonance (NMR) spectral analyses were performed at $60 \mathrm{MHz}$ Tesla BS-467 (Czech Republic) NMR spectrometer operating at $28^{\circ} \mathrm{C}$. Compounds were dissolved in $\mathrm{CDCl}_{3}$.

\section{RESULTS}

As a result, bioconversion 4-methylpyridine (I) was isolated substance II and identified as 4methylpyridin-2-ol (Table 1). Compound II has been accumulating in the log phase (18-20 hours) and decreases in the stationary phase (36 hours). 
Compound II is completely disappear from the incubation liquid to 36 hours of incubation. Also, was isolated the blue pigment (III) but only in amounts sufficient for mass spectral analysis. In the ${ }^{1} \mathrm{H}$ NMR spectrum of compound II was observed doublet of proton H-6 with a chemical shift of 6.37 $\operatorname{ppm}\left(J_{5,6}=6.6 \mathrm{~Hz}\right)$, broad singlet of proton $\mathrm{H}-3$ with a chemical shift of $6.37 \mathrm{ppm}$, doublet of doublets of the proton $\mathrm{H}-5$ with a chemical shift of $6.12 \mathrm{ppm}\left(J_{3,5}\right.$ $=1.7 \mathrm{~Hz}, J_{5,6}=6.6 \mathrm{~Hz}$ ) and three protons of the methyl group with a chemical shift of $2.23 \mathrm{ppm}$.

Based on mass spectral analysis the blue pigment had the structure of substituted diazafluorene (III), which is possibly was formed from the diazaquinone (IIIa) as a result of dehydration reaction (Table 2, Fig. 1).

Figure 2 shows alleged the mechanism of the degradation of 4-methylpyridine by bacterium Arthrobacter sp. KM-4MP.

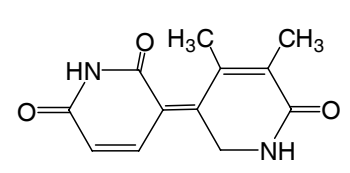

IIIa
III

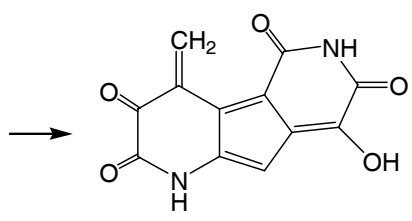

Fig. 1. The structure of the blue pigment which was synthesized by Arthrobacter sp. KM-4 MP, in time of growing on 4-methylpyridine. IIIa diazaquinone; III - diazafluorene.

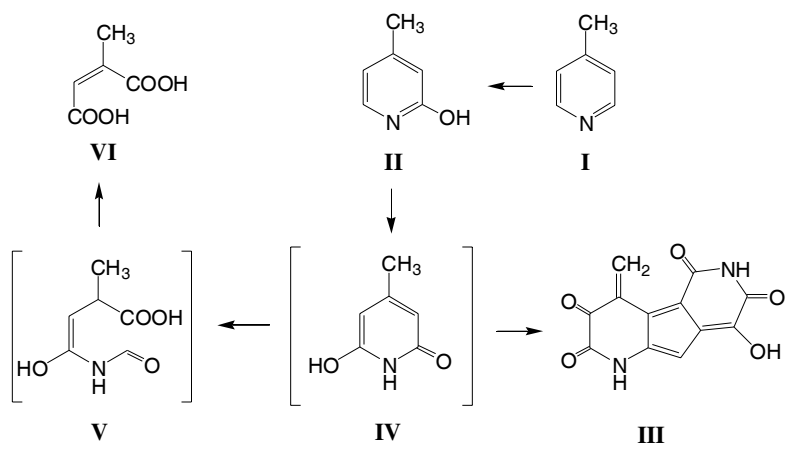

Fig. 2. The catabolism of 4-methylpyridine (I) by the strain of Àrthrobacter sp. KM-4MP; II - 4methylpyridin-2-ol; III-8-hydroxy-4methylidene-1H-cyclopenta[1,2-b:3,4-c'] dipyridine-2,3,5,7(4H,6H)-tetrone (blue pigment); IV and V - possible intermediates; VI methylmaleic acid.

\section{DISCUSSION}

Typically, such processes of biodegradation ending by accumulation of dicarboxylic acids (such as methylmaleic acids) in incubation fluid, but we were not able to isolate these substances in sufficient quantities for analysis (Kost et al., 1977).

The literature contains information about pigment formation in the oxidation of pyridine derivatives. The common name for that is azaquinones. Formation of blue pigment was observed in the metabolism of nicotinic acid by

Table 1. Mass spectrum of 4-methylpyridin-2-ol (II)

\begin{tabular}{cccl}
\hline $\begin{array}{l}\text { Structure of } \\
\text { compound II }\end{array}$ & $m / z$ & Relative abundance, $\%$ & $\begin{array}{l}\text { The formation } \\
\text { of fragments }\end{array}$ \\
\hline $\mathrm{CH}_{3}$ & 109 & 100 & $\mathrm{M}^{+}$ \\
& 81 & 10 & $\mathrm{M}^{+}-\mathrm{CO}$ \\
& 80 & 54 & $\mathrm{M}^{+}-\mathrm{HCO}$ \\
& 53 & 17 & $\mathrm{M}^{+}-\mathrm{HCO}-\mathrm{HCN}$ \\
\hline
\end{tabular}

Table 2. Mass spectrum of diazafluorene (8-hydroxy-4-methylidene-1H-cyclopenta[1,2-b:3,4-c']dipyridine2,3,5,7(4H,6H)-tetrone)

\begin{tabular}{llll}
\hline $\begin{array}{l}\text { Structure of } \\
\text { compound III }\end{array}$ & $m / z$ & Relative abundance, $\%$ & $\begin{array}{l}\text { The formation } \\
\text { of fragments }\end{array}$ \\
\hline & 259 & 100 & $\begin{array}{l}\mathrm{M}^{+} \\
\mathrm{M}^{+}-\mathrm{OH}\end{array}$ \\
$\mathrm{M}^{+}-\mathrm{OH}-\mathrm{HOH}$ \\
$\mathrm{M}^{+}-\mathrm{H}_{2}-\mathrm{NCO}$ \\
$\mathrm{M}^{+}-\mathrm{OH}-\mathrm{HOH} 2 \mathrm{CO}$ \\
$\mathrm{M}^{+}-\mathrm{CH}_{3}-\mathrm{CO}-\mathrm{CO}-\mathrm{NH}$
\end{tabular}


microorganisms of the genus Bacillus (Ensign et al., 1965), of nicotine, or of 2-hydroxypyridine by bacteria A. crystallopoietes, or by strains of Arhtrobacter (Kolenbrander, 1977).

Thus, the degradation of 4-methylpyridine by bacteria Àrthrobacter sp. KM-4MP happening thru the initial hydroxylation of the pyridine ring.

It is known that during degradation of 2- and 4ethylpyridine by a mixed culture of bacteria from soil initially happening hydroxylation then cleavage of ring (Feng et al., 1994).

It was also found that the process of degradation of 2-, 3-, and 4-methylpyridines by fungi stops at the formation of the corresponding hydroxymethyl pyridines (Modyanova et al., 1990).

It was established that hydroxylation of 4hydroxypyridine by strain Agrobacterium sp. $35 \mathrm{~S}$ to 3,4-dihydroxypyridine catalyzes enzyme monooxygenase. (Houghton et al., 1972).

We can assume that the source of oxygen in the oxidation of the heterocyclic ring of 4methylpyridine by strain Arthrobacter sp. KM-4MP is molecular oxygen, and the enzyme that catalyzes this reaction are a class of monooxygenases.

\section{ACKNOWLEDGEMENT}

We thank Dr. P. B. Terent'ev for help in interpretation of mass spectrums.

\section{REFERENCES}

Dobson, K.R., Stephenson, M., Greenfield, P.F. and Bell, P.R.F. 1985. Identification and treatability of organics in oil shale retort water. Wat. Res. 19: 849-56.

Ensign, J.C. and Rittenberg, S.C. 1965. The formation of a blue pigment in the bacterial oxidation of isonicotinic acid. Arch. Microbiol. 51: 384-92.

Feng, Y., Kaiser, J.P., Minard, R.D. and Bollag, J.M. 1994. Microbial transformation of ethylpyridines. Biodegradation. 5: 121-128.
Houghton, C. and Cain, R.B. 1972. Microbial metabolism pyridine ring. Formation of pyridine diols (dihydroxyperidine) as intermediates in the degradation of pyridine compounds by microorganisms. J. Biochem. 190 : 879-93.

Kaiser, J.P., Feng, Y. and Bollag, J.M. 1996. Metabolism of pyridine, qunoline, acridine and derivatives under aerobic and anaerobic conditions. Microbiol. Rev. 60: 483-98.

Khasaeva, F.M. and Parshikov, I.A. 2015. Biodegradation of 2,4-dimethylpyridine by Rhodococcus erythropolis. International Journal of Nanobiotechnology and Pharmacy. 1: 4-11.

Kolenbrander, P.E. and Weinberger, M. 1977. 2Hydroxypyridine metabolism and pigment formation in three Arthrobacter sp. J. Bacteriol. 132: 51-9.

Kost, A.N., Vorob'eva, L.I., Terent'ev, P.B., Modyanova, L.V., Shibilkina, O.K. and Korosteleva, L.A. 1977. Microbiological transformation of 2,6dimethylpyridine. Appl. Biochem. Microbiol. 13: 54146.

Modyanova, L.V., Vorob'eva, L.I., Shibilkina, O.K., Dovgilevich, E.V. and Terent'ev, P.B. 1990. Microbiological transformations of nitrogencontaining heterocyclic compounds. I. Hydroxylation of isomeric methyl- and dimethylpyridines by certain microscopic fungi. Sov. Botechnol. 3 : 24-7.

Parshikov, I.A. 2015a. Microbial Conversions of Nitrogenous Heterocycles. Publishing House Editus Ltd, Moscow. $130 \mathrm{p}$.

Parshikov, I.A. 2015b. Microbial Conversions of Terpenoids. Publishing House Editus Ltd, Moscow. 100 p.

Parshikov, I.A., and Khasaeva, F.M. 2015. Bioconversion of 2-ethylpyridine by Beauveria bassiana. Young Scientist. 15 : 241-43.

Pereira, W.E., Rostand, C.E., Leiker, T.J., Updergraff, D.M. and Beennett, J.L. 1988. Microbial hydroxylation of quinoline in contaminated groundwater: evidence for incorporation of the oxygen atom of water. J. Appl. Eviron. Microbiol. 54 : 827-29.

Rogers, J.E., Riley, R.G., Li, S.W., O'Malley, M.L. and Thomas, B.L. 1985. Microbial transformation of alkylpyridines in groundwater. Water, Air and Soil Pollution. 24 : 443-54. 